\title{
Identifying habitat and understanding movement resistance for the Endangered Bornean banteng Bos javanicus lowi in Sabah, Malaysia
}

\author{
Hong Ye Lim, Penny C. Gardner, Nicola K. Abram \\ Kalsum M. Yusah and Benoit Goossens
}

\begin{abstract}
Habitat prioritization and corridor restoration are important steps for reconnecting fragmented habitats and species populations, and spatial modelling approaches are useful in identifying suitable habitat for elusive tropical rainforest mammals. The Endangered Bornean banteng Bos javanicus lowi, a wild bovid endemic to Borneo, occurs in habitat that is highly fragmented as a result of extensive agricultural expansion. Based on the species' historical distribution in Sabah (Malaysia), we conducted camera-trap surveys in 14 forest reserves during 2011-2016. To assess suitable habitat for the banteng we used a presence-only maximum entropy (MaxEnt) approach with 11 spatial predictors, including climate, infrastructure, land cover and land use, and topography variables. We performed a least-cost path analysis using Linkage Mapper, to understand the resistance to movement through the landscape. The surveys comprised a total of 44,251 nights of camera trapping. We recorded banteng presence in 11 forest reserves. Key spatial predictors deemed to be important in predicting suitable habitat included soil associations (52.6\%), distance to intact and logged forests (11.8\%), precipitation in the driest quarter $(10.8 \%)$, distance to agroforest and regenerating forest $(5.7 \%)$, and distance to oil palm plantations (5.1\%). Circa $11 \%$ of Sabah had suitable habitat $\left(7,719 \mathrm{~km}^{2}\right)$, of which $12.2 \%$ was in protected forests, $60.4 \%$ was in production forests and $27.4 \%$ was in other areas. The least-cost path model predicted 21 linkages and a relatively high movement resistance between core habitats. Our models provide information about key habitat and movement resistance for bantengs through the landscape, which is crucial for constructive conservation strategies and land-use planning.
\end{abstract}

Hong Ye LiM* (Corresponding author, (1) orcid.org/0000-0003-0699-5187) and KaLsum M. YusaH Institute for Tropical Biology and Conservation, Universiti Malaysia Sabah, Kota Kinabalu, Sabah, Malaysia

E-mail limhongye90@gmail.com

Penny C. Gardner $\dagger$ and Benoit Goossens $\dagger \neq$ Danau Girang Field Centre, Sabah Wildlife Department, Kota Kinabalu, Sabah, Malaysia

Nicola K. Abram§ Living Landscape Alliance, Berkshire, UK

*Also at: Danau Girang Field Centre, Sabah Wildlife Department, Wisma Muis, Kota Kinabalu, Sabah, Malaysia

$\dagger$ Also at: Organisms and Environment Division, Cardiff School of Biosciences, Cardiff University, UK

$¥$ Also at: Sustainable Places Research Institute, Cardiff University, Cardiff, UK $\$$ Also at: ARC Centre of Excellence for Environmental Decisions, The University of Queensland, Brisbane, Australia

Received 2 February 2018. Revision requested 17 April 2018.

Accepted 10 August 2018. First published online 21 May 2019.
Keywords Bornean banteng, Borneo, Bos javanicus lowi, conservation, habitat suitability, maximum entropy, movement resistance, Sabah

Supplementary material for this article is available at https://doi.org/10.1017/Soo30605318001126

\section{Introduction}

T uman-induced destruction of natural ecosystems 1 is one of the major threats to global biodiversity (Cincotta et al., 2000), with c. $28 \%$ of all known species threatened by destructive human activities (IUCN, 2016). Endemic species of Borneo are among the most vulnerable to timber extraction, deforestation for oil palm, habitat fragmentation and poaching (Gaveau et al., 2014; Hoffmann et al., 2016). Effective protection of these species requires a strategic conservation approach, involving in particular habitat protection and connectivity restoration (Koh \& Sodhi, 2010).

In this study our focal species was the Bornean banteng Bos javanicus lowi, a wild bovid subspecies endemic to Borneo (Gardner et al., 2016; Ishige et al., 2016). There are two other subspecies, the mainland banteng $B$. javanicus birmanicus (Indochina) and the Javan banteng B. javanicus javanicus (Java and Bali); all three are categorized as Endangered on the IUCN Red List (Gardner et al., 2016). Bornean bantengs inhabit primary and secondary dipterocarp and swamp forests and are best described as mixedfeeders (Gardner et al., 2014). They endure secondary forest conditions and benefit from the temporary increases in regenerating vegetation in early stages of a logged forest but only when human disturbances are infrequent (Gardner, 2015; Prosser et al., 2016; Journeaux et al., 2018). When the ambient temperature is high they rest in the shade of closed canopy forest to reduce heat stress and avoid dehydration (Gardner, 2015). They favour foraging ground close to permanent water sources, where they also socialize (Davies \& Payne, 1982). Deforestation and the establishment of extensive monoculture plantations, especially of oil palm, have resulted in a highly fragmented population (Gardner, 2015).

Banteng occurrence records in Sarawak (Malaysian Borneo), Brunei and Kalimantan (Indonesian Borneo) are 
scarce and our understanding of the banteng's distribution across its range in Borneo is limited (Gardner et al., 2014). For Sabah, Davies \& Payne (1982) published the first statewide banteng distribution map, and estimated a population size of c. 300-500 individuals. However, the community interviews and sign surveys they used were dependent on accessibility. Boonratana (1997) used line transects to identify banteng presence in several forest reserves in Sabah, and estimated the population to be $<300$ individuals. Indirect density estimation based on dung was impossible because of low encounter rates along the line transects, which covered a total distance of $62 \mathrm{~km}$. Gardner (2015) estimated the population size in Tabin Wildlife Reserve (52 individuals) and Malua Forest Reserve ( 35 individuals) using photographic evidence captured by camera traps. Localized extinctions have occurred in the Dent Peninsula of Sabah (Gardner, 2015).

The increasing availability of spatial modelling approaches, and higher-quality and relevant environmental data facilitate habitat prioritization and connectivity restoration (Beier et al., 2008; Elith \& Leathwick, 2009). However, spatial modelling has not been used previously to examine distribution patterns of the Bornean banteng. Among the available modelling methods, maximum entropy (MaxEnt) is popular because it can model presence-only data and multidimensional interactions between variables (Elith et al., 2011). Trisurat et al. (2015) used MaxEnt to model current and future distribution patterns of the mainland banteng in northern Thailand under scenarios of changes in land use and climate, and highlighted areas in need of protection. MaxEnt has also been used for distribution modelling for other Bornean and Malayan taxa; e.g. the flat-headed cat Prionailurus planiceps, Malayan sun bear Helarctos malayanus and Bornean ferret badger Melogale everetti (Wilting et al., 2010, 2016; Nazeri et al., 2012).

Identifying potential connectivity for reconnecting forest fragments is crucial for the banteng, as habitat fragmentation has disrupted movement and, potentially, gene flow (Hu et al., 2010; Gardner, 2015). Linkage Mapper (McRae \& Kavanagh, 2011) can be used to simulate potential wildlife corridors and movement resistance. Brodie et al. (2015) predicted and compared efficiency between multispecies and single-species corridors in Borneo but excluded the Bornean banteng from the analysis because of its restricted distribution.

A better understanding of current banteng distribution and identification of suitable habitats and movement resistance across Sabah are necessary for planning and drafting policy to protect the species. The aim of this study was therefore to enhance our knowledge of the distribution of the Bornean banteng in Sabah, Malaysia, by identifying suitable habitat and then estimating the resistance of movement of banteng between habitat patches. This research will inform the Species Action Plan for the Bornean banteng, and other conservation efforts in Sabah.

\section{Study area}

Our study covered the Malaysian state of Sabah, in the north of Borneo. Based on the historical distribution of the Bornean banteng (Davies \& Payne, 1982), we conducted camera-trap surveys in 14 forest reserves (Fig. 1). Forests in these reserves consisted of primary and secondary tropical lowland and mixed hill dipterocarp forest, montane forest and seasonal swamp forest. A history of various management approaches and timber harvesting regimes has resulted in an extensive network of logging roads, trails and openings. In Sabah forests are categorized as Protection Forest Reserves, Production Forest Reserves and Protected Areas. Both Protection and Production Forest Reserves are under the authority of Sabah Forestry Department, whereas Protected Areas are governed by Sabah Parks and Sabah Wildlife Department (Supplementary Material 1; Sabah Forestry Department, 2015).

\section{Methods}

\section{Camera trapping}

We deployed Reconyx HC50o and PC80o camera traps (Reconyx Inc., Holmen, USA) in the 14 forest reserves during 2011-2016 to detect the occurrence of Bornean bantengs, using grid (Gardner, 2015) and opportunistic sampling designs (Supplementary Table 1). Four grids were established in Tabin Wildlife Reserve and three in Malua Forest Reserve (Gardner, 2015). To avoid resampling the same banteng herds, the grids were spaced at least $10 \mathrm{~km}$ apart, as bantengs have been observed to travel at least $10 \mathrm{~km}$ (Gardner et al., 2014). The distance between camera-trap stations in each grid was c. $500 \mathrm{~m}$, to increase the chances of detection (Gardner, 2015). The total number of camera-trap stations used in the grid surveys was 231 . We employed an opportunistic sampling design in the remaining 12 forest reserves, to locate remnants of the banteng population. A total of 325 camera-trap stations were established in these reserves, based on the presence of banteng signs such as footprints and dung, on wildlife trails, riverbanks, ridges, active and abandoned logging roads, stumping sites and in both open and closed-canopy conditions. Each camera-trap station comprised two opposing camera traps and captured three images per trigger (one image per second), each stamped with the time, date and ambient temperature. We recorded the location of each station using a GPS. All stations operated $24 \mathrm{~h}$ per day for at least 90 days. Every 30 days we performed maintenance checks to ensure functionality of camera traps and retrieve data. 


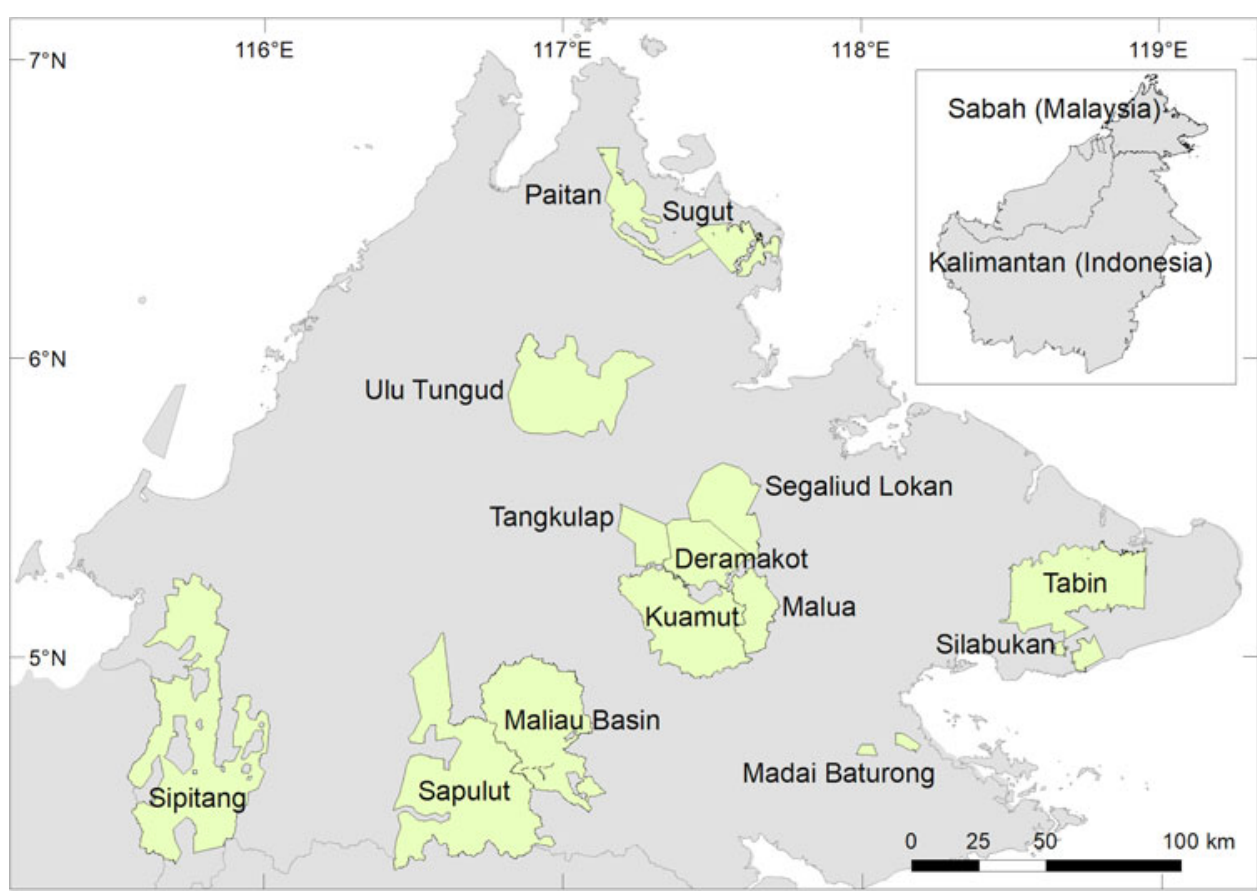

FIG. 1 Areas surveyed for the Bornean banteng Bos javanicus lowi in Sabah, Malaysia.

\section{Preparation of banteng occurrence data for MaxEnt}

MaxEnt uses presence-only data against background points. We used the coordinates of the stations at which bantengs were positively identified for our presence-only dataset. To minimize the effect of spatial autocorrelation, presence data were filtered by creating a 1-km circular buffer around each camera station (in ArcGIS 10.3; ESRI, Redlands, USA) and removing points within the buffer.

\section{Preparation of spatial predictors}

We used 11 spatial predictors, covering climate, infrastructure, land cover and land use, soil, and topographical variables, to describe the environmental conditions of the landscape (Supplementary Tables 2,3). These facilitate multidimensional exploration of the impact of precipitation and temperature variation, geographical features and human-induced modification of natural landscapes. These predictors were extracted at a 90-m resolution $(8,680,755$ cells $)$ covering the state of Sabah, excluding several small islands.

\section{Habitat suitability modelling}

We used MaxEnt v.3.3.3k (Phillips et al., 2006; Phillips \& Dudík, 2008) to associate the spatial predictors with the presence data. The MaxEnt approach is suitable for modelling a rare and low-density mobile species that occurs in a tropical rainforest where absence data can be highly unreliable and data collection is often difficult (Elith et al., 2011).
We assessed various combinations of the number of background points, regularization multiplier and features, selected the parameters with area under the receiver operating curve (AUC) $>0.90$ and less overfitting, and predicted all areas where bantengs were present. The final model specifications were 10,000 background points, a regularization multiplier of 1.o, linear, quadratic and product features, 500 iterations, true response curves, true jackknife test to measure variable importance, and logistic output. We chose a threshold of 0.24 based on the prevalence of banteng occurrence in our presence-absence dataset. To account for sampling bias we included a bias grid raster layer in the modelling process (Syfert et al., 2013). Point density in ArcGIS was used to generate the bias grid raster; the neighbourhood was set to a default. To avoid MaxEnt dropping the bias grid raster during the modelling, all zero values of the bias grid raster were converted to 0.00000001. A nested 10-fold cross-validation was applied to evaluate the predictive performance of the model using the AUC score, which indicates the model's ability to discriminate between presence and absence: $<0.5$, poor; 0.5-0.7, low, but better than chance; 0.7-0.9, intermediate; $>0.9$, high (Manel et al., 2001). To build a binary map of suitable and unsuitable habitats, four commonly used thresholds were assessed visually, namely minimum training presence, ten percentile training presence, equal training sensitivity and specificity, and maximum training sensitivity and specificity (Liu et al., 2005, 2013). To take into account all banteng habitat for protection, we selected the threshold that predicted the widest coverage of suitable areas. The suitable areas were restricted to forested areas, using a generic forest layer digitized from SPOT 5 and 6 satellite 
images from 2014 and 2015. This is because we assume the Bornean banteng to be largely a forest-dependent species, and therefore we considered areas of oil palm, smallholdings and settlements to be unsuitable. Areas $<100 \mathrm{~km}^{2}$ were removed, as bantengs travel at least $10 \mathrm{~km}$ (Gardner et al., 2014). Areas $\geq 100 \mathrm{~km}^{2}$ were assigned as core areas.

\section{Least-cost path analysis}

We performed a least-cost path analysis using Linkage Mapper v.1.1.o (McRae \& Kavanagh, 2011), to examine the movement resistance for the Bornean banteng across the Sabah landscape. The core suitable area was extracted and exported as a polygon shapefile (WHCWG, 2010). To create a resistance layer, the continuous habitat suitability raster layer was inverted and rescaled to 1-100 (Stevenson-Holt et al., 2014). As Linkage Mapper does not simulate cells with no value, they were converted to 101. Given the lack of knowledge in determining the optimal corridor width for bantengs, the effect of various corridor cut-off widths $(5,10$, 30,50 and $100 \mathrm{~km}$ cost-weighted distance) on the movement resistance output were evaluated (Dutta et al., 2016).

\section{Results}

\section{Camera trapping}

Because of electronic failure and malfunction, and unwarranted human activities, the total number of camera-trap nights was 44,251, and we obtained 111 presence and 411 absence data points. Bantengs were present in 11 of the 14 sites, namely Tabin Wildlife Reserve, Maliau Basin Conservation Area (buffer zone), and Malua, Deramakot, Tangkulap, Segaliud-Lokan, Kuamut, Sipitang, Sapulut, Sugut and Paitan Forest Reserves. After filtering was applied, 73 presence data points remained and were used for the analysis. Our camera traps also detected two snare injuries: a cow with a swollen hoof in Sugut and a bull with a missing hoof in Segaliud-Lokan.

\section{Habitat suitability}

The habitat suitability model had a high AUC score for model fitting (0.978) and 10-fold cross-validation (mean $=0.96 \pm$ SD 0.02). The five most influential spatial predictors were soil association (i.e. 52.6\% of the model contributed by soil association compared with the other 11 predictors), distance to intact and logged forests (11.8\%), precipitation in the driest quarter (10.8\%), distance to agro- and regenerating forest (5.7\%), and distance to oil palm (5.1\%; Table 1). Suitable habitat was highly associated with specific soil types, especially Kalabakan, Labau and Lokan (numbers 13, 21 and 22, respectively, in Fig. 2a),
TABLE 1 Per cent contribution of 11 spatial variables to the habitat suitability model for the Bornean banteng Bos javanicus lowi.

\begin{tabular}{ll}
\hline Environmental predictors & \% contribution \\
\hline Soil association & 52.6 \\
Distance to intact \& logged forest & 11.8 \\
Precipitation of driest quarter & 10.8 \\
Distance to agro- \& regenerating forest & 5.7 \\
Distance to oil palm & 5.1 \\
Distance to major river & 3.5 \\
Seasonality of precipitation & 3.2 \\
Distance to asphalt \& gravel road & 2.3 \\
Distance to severely degraded forest & 2.2 \\
Elevation & 1.8 \\
Annual temperature range & 1.2 \\
\hline
\end{tabular}

within or close to intact or logged forests (Fig. 2b), and in areas with relatively higher precipitation in the driest quarter of the year (Fig. 2c). The relationship between habitat suitability and distance to oil palm and agro- and regenerating forests increased with distance up to $30 \mathrm{~km}$ (Fig. 2d,e; Supplementary Fig. 1).

We selected the minimum training presence threshold (Supplementary Fig. 2) to define categories of suitable and unsuitable areas on the habitat suitability model, as it had zero omission rate and predicted the widest distribution of habitat for bantengs compared to other thresholds. Circa $11 \%\left(7,719 \mathrm{~km}^{2}\right)$ of Sabah was predicted to have suitable habitat, c. $12 \%\left(940 \mathrm{~km}^{2}\right)$ of which was within Protected Areas and Protection Forest Reserves, $60 \%\left(4,665 \mathrm{~km}^{2}\right)$ was within Production Forest Reserves, and $27 \%\left(2,114 \mathrm{~km}^{2}\right)$ was outside these areas (Table 2; Fig. 3).

\section{Least-cost path and movement resistance}

We identified 17 core habitat areas (101-2,133 $\left.\mathrm{km}^{2}\right)$ for bantengs, with a majority concentrated within the central forest (Supplementary Table 4; Fig. 3). The least-cost path model estimated 21 corridors. The least-cost path distance was $0.1-164.6 \mathrm{~km}$, with a mean of $26 \pm$ SD $41.7 \mathrm{~km}$. The cost-weighted distance was $3.5-16,797 \mathrm{~km}$, with a mean of $2,612.7 \pm \mathrm{SD} 4,254.9 \mathrm{~km}$. The mean ratio of cost-weighted distance to least-cost path was $92.5 \pm$ SD 18.4, indicating a relatively high movement resistance for travelling between the core areas. The path connecting core areas 11 and 12 (both within Deramakot) was the least costly for bantengs (38.5). The path between core areas 5 and 12 (Segaliud and Kulamba) was the most costly (102.8). The $100 \mathrm{~km}$ cut-off width was selected because $>50 \%$ of the cost-weighted corridors contained $>50 \%$ forest and $<50 \%$ oil palm (Fig. 3).

\section{Discussion}

Continuous habitat loss, fragmentation and poaching are the major threats to the Bornean banteng in Sabah. The 

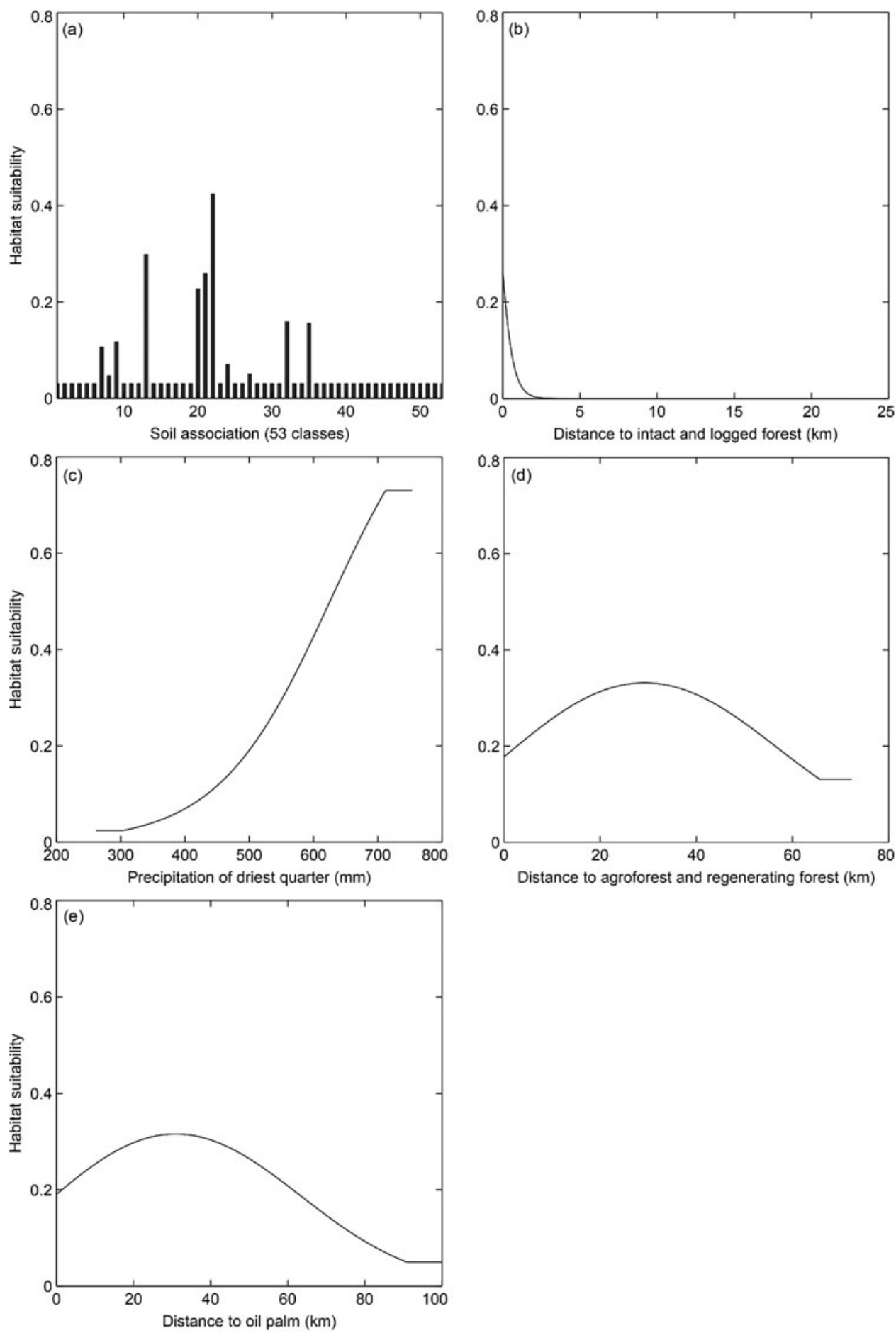

Fig. 2 Top five most influential spatial predictors in the MaxEnt model of habitat suitability for the Bornean banteng: (a) soil association (52.6\%); (b) distance to intact and logged forest (11.8\%); (c) precipitation of driest quarter (10.8\%); (d) distance to agroforest and regenerating forest $(5.7 \%)$; and (e) distance to oil palm plantations (5.1\%).

dearth of up-to-date knowledge of distribution and population size impedes conservation of this threatened species. Our goal was to describe the current distribution of suitable habitat, and movement resistance for bantengs.

\section{Habitat suitability}

Across Sabah we predicted that c. $11 \%$ of the land area has suitable habitat for bantengs. We found a strong association between soil types and habitat suitability, especially in Kalabakan, Lokan and Labau. Although the relationship between mammals and soil variability in Borneo is understudied, soil types may have indirect impacts on wildlife habitats as a result of floristic patterns (Woinarski et al., 1999). Variation in soil nutrient content determines tropical floristic composition, density and distribution (Paoli et al., 2006). Sedimentary soils (in Kalabakan and Labau) are common in both lowland and highland areas, whereas 
TABLE 2 Areas suitable and unsuitable for the Bornean banteng in Sabah (Fig. 3), and areas protected and unprotected.

\begin{tabular}{lrr}
\hline & Area $\left(\mathrm{km}^{2}\right)$ & \multicolumn{1}{c}{$\%$} \\
\hline Suitability & & \\
Suitable area & 7,719 & 10.6 \\
Unsuitable area & 64,994 & 89.4 \\
Total & 72,713 & 100.0 \\
Protection status & & \\
Protection Forest Reserves \& & 940 & 12.2 \\
$\quad$ Protected Areas & & \\
Production Forest Reserves & 4,665 & 60.4 \\
Outside Forest Reserve \& Protected Areas & 2,114 & 27.4 \\
Total & 7,719 & 100.0 \\
\hline
\end{tabular}

alluvium (in Lokan) prevails in the coastal zones, floodplains and major rivers, and both sedimentary and alluvium are dominated by dipterocarp species (Paoli et al., 2006). Both sedimentary and alluvial soils are widespread across Sabah, indicating that intact dipterocarp forest might have been common historically throughout the landscape before intensive logging and forest clearance for oil palm and other land use. Bantengs could therefore have inhabited dipterocarp forest before extensive land-use change.

The Bornean banteng is a forest-dependent species and our model also highlighted the importance of logged forests. Logged forest is common in Production Forest Reserves and some Protected Areas and Protection Forest Reserves (e.g. Tabin Wildlife Reserve). Pioneer vegetation (i.e. vines, herbs and grasses) prevails in logged forests as a result of increased light levels on the forest floor, and this is favourable for the banteng (Gardner et al., 2014; Prosser et al., 2016). Forage preferences, however, may not be the only reason the model identified suitable habitat in logged forests, as intact forest in Sabah is scarce as a result of expansive historical and current logging regimes. The available intact forest is largely confined to Maliau basin, categorized by very steep slopes that are impassable to bantengs, and Danum Valley Conservation Area, which was reportedly occupied by bantengs in 2013 (Gardner et al., 2014) but was not surveyed in this study. The extent of protected intact forest in 2009 was only $8 \%$ (Bryan et al., 2013), which may explain the common sighting of bantengs in degraded forests.

Our model indicated that higher precipitation rates during the driest months improved habitat suitability, suggesting bantengs are potentially drought sensitive. Little is known about the effect of drought on wildlife in Borneo but Hoogerwerf (1970) noted that dry seasons shaped the distribution of the Javan banteng because the foraging areas, quality of foraging resources and availability of freshwater diminished, resulting in intensified competition with other ungulates for these scarce resources. During periods of drought these conditions would be exacerbated. The water content in the topsoil governs the survival of regenerating plants such as herbs (Poulsen, 1996), and this may limit foraging resources for bantengs. Areas that receive occasional rainfall during the dry season and drought are probably more suitable for this species.

\section{Management of banteng habitat}

Only c. $12 \%\left(940 \mathrm{~km}^{2}\right)$ of the area suitable for bantengs was within Sabah's protected forests (i.e. Protected Areas and Protection Forest Reserves). In these areas forest harvesting and crop plantations are prohibited. Logged forest is present in most of them because they were under various logging regimes before protection. Circa $60 \%\left(4,665 \mathrm{~km}^{2}\right)$ of banteng habitat fell within Production Forest Reserves, where harvesting of natural forest, tree plantations (acacia, eucalyptus or native species), mosaic forests and oil palm are permissible (although no new planting of oil palm can occur). Although Production Forest Reserves are under the authority of Sabah Forestry Department, the forests within the banteng's habitat are largely managed by Yayasan Sabah or other concession holders. Understanding where banteng habitat is located is critical for conservation decision making, especially as more tree plantations and mosaic areas will be established in the region. The remaining $27 \%$ of habitat $\left(7,719 \mathrm{~km}^{2}\right)$ outside protected or production forests (Fig. 3 ) is mainly around Sipitang, Paitan and Sapulut and is susceptible to timber harvesting or clearance for other land uses.

The size of the banteng population in Sabah is unknown but there are outdated estimates of 300-500 individuals (Davies \& Payne, 1982). Our modelling of suitable habitat suggests these are spread across four populations. In 2017 there were four known cases of banteng poaching (New Sabah Times, 2017), which is probably an underestimate as many cases of poaching remain unreported. The extensive network of active and abandoned logging roads and the expansion of new public roads (e.g. the Pan Borneo Highway) will exacerbate the risk of poaching, as poachers can access remote forest areas by car, motorcycle or foot. Decreasing accessibility for poachers is one of Sabah Forestry Department's aims (Daily Express, 2015), and should be taken into consideration in development plans for road construction. Davies \& Payne (1982) and Boonratana (1997) noted that hunting was one of the main causes of the decline of banteng populations in Sabah, and our camera-trap stations detected two snare injuries. Given the banteng's cryptic nature, capture of individuals and removal of snares from trapped individuals is almost impossible, and therefore snare injuries are likely to cause fatal infections or physical impairment.

\section{Movement resistance}

Although the predicted least-cost path linkages are specific to the Bornean banteng and may not be suitable for other 


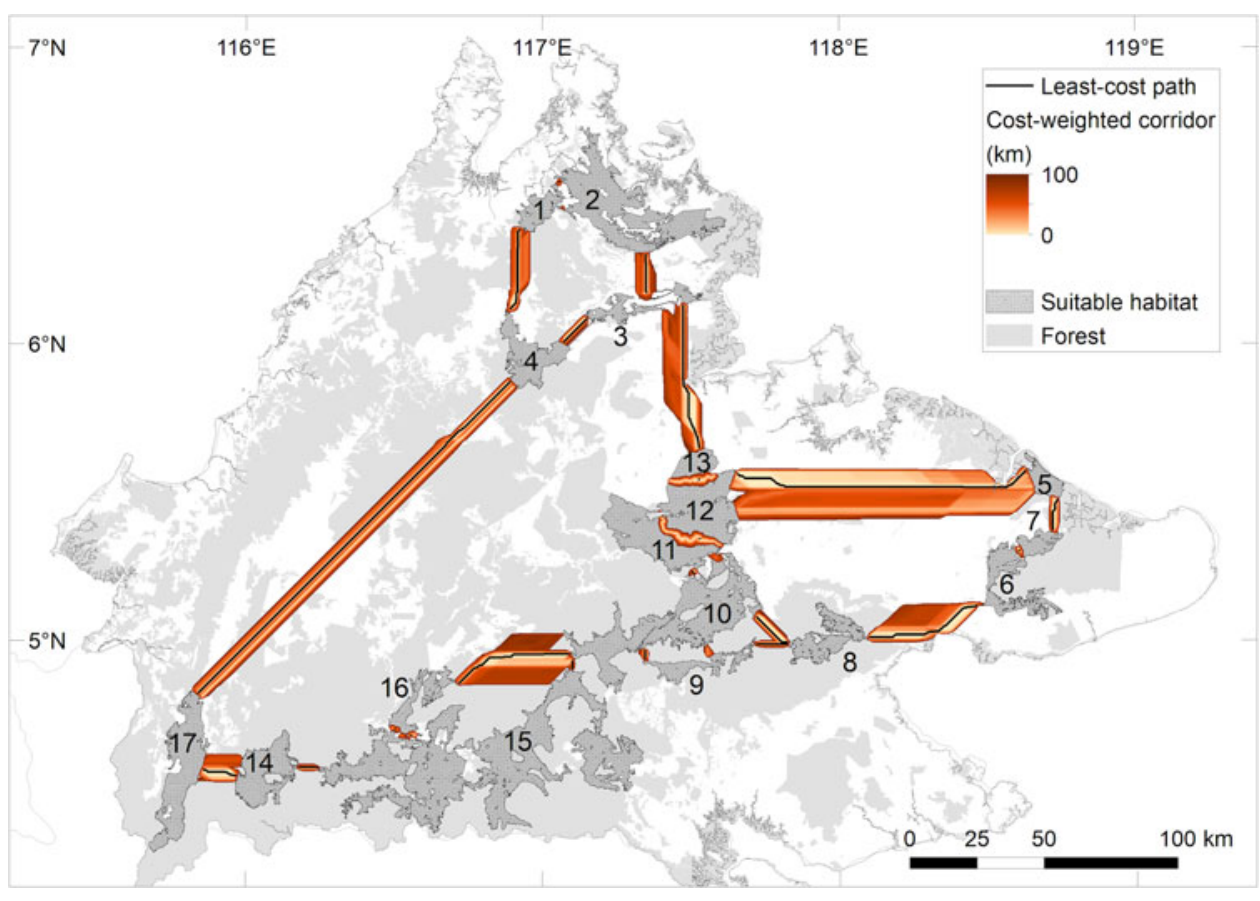

FIG. 3 Locations of the least-cost paths, $100 \mathrm{~km}$ cost-weighted corridors (from low to high cost-weighted distances in $\mathrm{km}$ ) and the 17 suitable habitats for the Bornean banteng, and forest, in Sabah. Details of the least-cost paths are in Supplementary Table 4. species, they reflect movement difficulty for bantengs across the Sabah landscape (Driezen et al., 2007). These predicted locations are potentially areas with the lowest cost for banteng dispersal, and the significance of this could be explored by decision makers.

The model predicted 21 linkages between 17 core habitats. The relatively high ratio of cost-weighted distance to least-cost path indicates a high level of difficulty for bantengs traversing the terrain. The key factors are severe habitat fragmentation and clearance for oil palm. This was evident in the $100 \mathrm{~km}$ cost-weighted corridors, which contained c. $40 \%$ oil palm. The linkage between core areas 5 and 12 (Kulamba and Segaliud) is the most difficult for banteng dispersal. Despite the presence of small forest patches along the Kinabatangan River, the area between these two core habitats is dominated by oil palm and separated by a highway.

The banteng population in Sabah can be grouped into south-western, north-eastern, western and central subpopulations that are geographically isolated. Our analysis suggests that banteng dispersal among these subpopulations is probably impossible because of high movement resistance.

\section{Method limitations and strengths}

Because of the generality of the spatial predictors, they serve as proxies to describe environmental characteristics that may determine the banteng's habitat preferences. Highresolution and comprehensive spatial data across the Sabah landscape are necessary to improve the robustness and accuracy of modelling output but the spatial data we used were the best available.
The combination of camera trapping and spatial modelling provides the most robust method of estimating banteng distribution across Sabah, and increased survey coverage, especially in areas where previous surveys failed to detect bantengs. Previous large-scale surveys used community-based surveys, line-transect and sign surveys to estimate banteng distribution (Davies \& Payne, 1982; Boonratana, 1997). As the species generally occurs at low density and avoids human presence, these survey methods are less efficient than camera trapping (Gardner, 2015).

The least-cost path analysis is limited in determining the appropriate corridor width (Brodie et al., 2015), and therefore we tested several cost-weighted distance cut-off widths to evaluate their suitability in the least-cost path model (Dutta et al., 2016). As the Bornean banteng is a forestdependent species, the $100 \mathrm{~km}$ cost-weighted cut-off width was selected, because at least $50 \%$ of the corridors were forest.

\section{Recommendations}

The habitat suitability model suggests that precipitation during the driest quarter is an influential predictor of habitat suitability for the banteng, but further information about the impact of drought on Bornean mammals is needed, especially in light of climate change, to understand the factors determining species' ranges. Maintenance of connectivity in the central forest should be a long-term conservation goal, as this is the largest patch of suitable banteng habitat in Sabah and may contain the largest population of bantengs. This forest patch consists of various forest management units, and plans for these will need to consider local banteng 
distribution patterns, forest conditions and hunting pressure. This information could also be incorporated in Sabah's Bornean Banteng Action Plan. Our surveys indicate that many forest reserves in Sabah are subject to poaching; strict enforcement and regulation should be in place to monitor and restrict unauthorized access to these areas.

Acknowledgements We thank the Sabah Wildlife Department, Datuk Sam Mannan and the Sabah Forestry Department, and the Sabah Biodiversity Centre for permission to conduct this research, and New Forests Pty Ltd and Malua BioBank for supporting our work. This study was funded by Yayasan Sime Darby, Houston Zoo (P. Riger), the Mohammed bin Zayed Species Conservation Fund, the Malaysian Palm Oil Council, and Woodland Park Zoo. We also thank the U.S. Embassy (Kuala Lumpur) for supporting HYL in his research, and the students, volunteers and local communities who assisted in the survey.

Author contributions Survey planning: HYL, PCG, BG; fieldwork: HYL, PCG; development of spatial layers: NKA; data analysis: HYL, NKA; writing: all authors.

\section{Conflicts of interest None.}

Ethical standards All authors have abided by the Oryx Code of Conduct. Permission for the state-wide survey was obtained from Sabah Wildlife Department, Sabah Forestry Department and Sabah Biodiversity Centre.

\section{References}

Beier, P., Majka, D.R. \& Spencer, W.D. (2008) Forks in the road: choices in procedures for designing wildland linkages. Conservation Biology, 22, 836-851.

Boonratana, R. (1997) A statewide survey to estimate the distribution and density of the Sumatran rhinoceros, Asian elephant and banteng in Sabah, Malaysia. PhD thesis. Mahidol University, Bangkok, Thailand.

Brodie, J.F., Giordano, A.J., Dickson, B., Hebblewhite, M., Bernard, H., Mohd-Azlan et al. (2015) Evaluating multispecies landscape connectivity in a threatened tropical mammal community. Conservation Biology, 29, 122-132.

Bryan, J.E., Shearman, P.L., Asner, G.P., Knapp, D.E., Aoro, G. \& LoKes, B. (2013) Extreme differences in forest degradation in Borneo: comparing practices in Sarawak, Sabah, and Brunei. PLOS ONE, 8, e69679.

Cincotta, R.P., Wisnewski, J. \& Engelman, R (2000) Human population in the biodiversity hotspots. Nature, 404, 990-992.

Daily Express (2015) Tighter access to forest reserves. Http://www. dailyexpress.com.my/news.cfm?NewsID $=96670$ [accessed 28 November 2015].

Davies, G. \& Payne, J. (1982) A Faunal Survey in Sabah. WWF Malaysia, Kuala Lumpur, Malaysia.

Driezen, K., Adriaensen, F., Rondinini, C., Doncaster, C.P. \& Matthysen, E. (2007) Evaluating least-cost model predictions with empirical dispersal data: a case-study using radiotracking data of hedgehogs (Erinaceus europaeus). Ecological Modelling, 209, 314-322.

Dutta, T., Sharma, S., McRae, B.H., Roy, P.S. \& DeFries, R. (2016) Connecting the dots: mapping habitat connectivity for tigers in central India. Regional Environmental Change, 16, 53-67.

Elith, J. \& Leathwick, J. (2009) Species distribution models: ecological explanation and prediction across space and time. Annual Review of Ecology, Evolution, and Systematics, 40, 677-697.
Elith, J., Phillips, S.J., Hastie, T., Dudík, M., Chee, Y.E. \& Yates, C.J. (2011) A statistical explanation of MaxEnt for ecologists. Diversity and Distributions, 17, 43-57.

GARDNER, P.C. (2015) The natural history, non-invasive sampling, activity patterns and population genetic structure of the Bornean banteng (Bos javanicus lowi) in Sabah, Malaysia. PhD thesis. Cardiff University, Cardiff, UK.

Gardner, C.P., Pudyatmoko, S., Bhumpakphan, N., Yindee, M., Ambu, D.L.N. \& Goossens, B. (2014) Banteng (Bos javanicus). In Ecology, Evolution, and Behaviour of Wild Cattle: Implication for Conservation (eds M. Melletti \& J. Burton), pp. 216-23o. Cambridge University Press, Cambridge, UK.

Gardner, P., Hedges, S., Pudyatmoko, S., Gray, T.N.E. \& Timmins, R.J. (2016) Bos javanicus. In The IUCN Red List of Threatened Species 2016: e.T2888A46362970. Http://dx.doi.org/10. 2305/IUCN.UK.2016-2.RLTS.T2888A46362970.en [accessed 4 December 2017].

Gaveau, D.L.A., Sloan, S., Molidena, E., Yaen, H., Sheil, D., A вram, N.K. et al. (2014) Four decades of forest persistence, clearance and logging on Borneo. PLOS ONE, 9, e101654.

Hoffmann, M., Hilton-Taylor, C., Angulo, A., Böhm, M., Brooks, T.M., Butchart, S.H.M. et al. (2016) The impact of conservation on the status of the world's vertebrates. Science, 330, 1503-1509.

Hoogerwerf, A. (1970) Ugjung Kulon: the Land of the Last Javan Rhinoceros, with Local and General Data on the Most Important Faunal Species and their Preservation in Indonesia. E.J. Brill, Leiden, The Netherlands.

Hu, Y., ZhAN, X., QI, D. \& WeI, F. (2010) Spatial genetic structure and dispersal of giant pandas on a mountain-range scale. Conservation Genetics, 11, 2145-2155.

Ishige, T., Gakuhari, T., Hanzawa, K., Kono, T., Sunjoto, I., SuKor, J.R.A. et al. (2016) Complete mitochondrial genomes of the tooth of a poached Bornean banteng (Bos javanicus lowi; Cetartiodactyla, Bovidae). Mitochondrial DNA Part A, 27, 2453-2454.

IUCN (2016) The IUCN Red List of Threatened Species. Http://www.iucnredlist.org [accessed 20 March 2017].

Journeaux, K.L., Gardner, P.C., Lim, H.Y., Wern, J.G.E. \& Goossens, B. (2018) Herd demography, sexual segregation and the effects of forest management on Bornean banteng Bos javanicus lowi in Sabah, Malaysian Borneo. Endangered Species Research, 35, 141-157.

Kон, L.P. \& SodHi, N.S. (2010) Conserving Southeast Asia's imperiled biodiversity: scientific, management, and policy challenges. Biodiversity and Conservation, 19, 913-917.

Liu, C., Berry, P.M., Dawson, T.P. \& Pearson, R.G. (2005) Selecting thresholds of occurrence in the prediction of species distributions. Ecography, 28, 385-393.

Liu, C., White, M. \& Newell, G. (2013) Selecting thresholds for the prediction of species occurrence with presence-only data. Journal of Biogeography, 40, 778-789.

Manel, S., Williams, H.C. \& Ormerod, S.J. (2001) Evaluating presence-absence models in ecology: the need to account for prevalence. Journal of Applied Ecology, 38, 921-931.

McRae, B.H. \& Kavanagh, D.M. (2011) Linkage Mapper Connectivity Analysis Software. The Nature Conservancy, Seattle, USA.

Nazeri, M., Jusoff, K., Madani, N., Mahmud, A.R., Bahman, A.R. \& Kumar, L. (2012) Predictive modeling and mapping of Malayan sun bear (Helarctos malayanus) distribution using Maximum Entropy. PLOS ONE, 7, e48104.

New Sabah Times (2017) Plantation manager behind one of banteng shootings, says Sabah Forestry Department. Https://www.nst.com. $\mathrm{my} /$ news/nation/2017/11/309221/plantation-manager-behind-onebanteng-shootings-says-sabah-forestry [accessed 30 November 2017]. 
Paoli, G.D., Curran, L.M. \& Zak, D.R. (2006) Soil nutrients and beta diversity in the Bornean Dipterocarpacea: evidence for niche partitioning by tropical rain forest trees. Journal of Ecology, 94, 157-170.

Phillips, S.J. \& Dudík, M. (2008) Modeling of species distributions with MaxEnt: new extensions and a comprehensive evaluation. Ecography, 31, 161-175.

Phillips, S.J., Anderson, R.P. \& Schapire, R.E. (2006) Maximum entropy modeling of species geographic distributions. Ecological Modelling, 190, 231-259.

Poulsen, A.D. (1996) Species richness and density of ground herbs within a plot of lowland rainforest in north-west Borneo. Journal of Tropical Ecology, 12, 177-19o.

Prosser, N.S., Gardner, P.C., Smith, J.A., Wern, J.G.E., Ambu, L.N. \& Goossens, B. (2016) Body condition scoring of Bornean banteng in logged forests. BMC Zoology, 1, 8.

Sabah Forestry Department (2015) Fact Sheets of Forest Reserves in Sabah (2015). Sabah Forestry Department, Sandakan, Malaysia.

Stevenson-Holt, C.D., Watts, K., Bellamy, C.C., Nevin, O.T. \& Ramsey, A.D. (2014) Defining landscape resistance values in least-cost connectivity models for the invasive grey squirrel: a comparison of approaches using expert-opinion and habitat suitability modelling. PLOS ONE, 9, e112119.
Syfert, M.M., Smith, M.J. \& Coomes, D.A. (2013) The effects of sampling bias and model complexity on the predictive performance of MaxEnt species distribution models. PLOS ONE, 8, e55158.

Trisurat, Y., Kanchanasaka, B. \& Kreft, H. (2015) Assessing potential effects of land use and climate change on mammal distributions in northern Thailand. Wildlife Research, 41, 522-536.

WHCWG (Washington Wildlife Habitat Connectivity Working Group) (2010) Washington Connected Landscapes Project: Statewide Analysis. Washington Departments of Fish and Wildlife, and Transportation, Olympia, Washington, USA.

Wilting, A., Cord, A., Hearn, A.J., Hesse, D., Mohamed, A., Traeholdt, C. et al. (2010) Modelling the species distribution of flat-headed cats (Prionailurus planiceps), an Endangered South-East Asian small felid. PLOS ONE, 5, e9612.

Wilting, A., Hearn, A.J., Eaton, J., Belant, J.L. \& KramerSchadt, S. (2016) Predicted distribution of the Bornean ferret badger Melogale everetti (Mammalia: Carnivora: Mustelidae) on Borneo. The Raffles Bulletin of Zoology, 33, 55-60.

Woinarski, J.C.Z., Fisher, A. \& Milne, D. (1999) Distribution patterns of vertebrates in relation to an extensive rainfall gradient and variation in soil texture in the tropical savannas of the Northern Territory, Australia. Journal of Tropical Ecology, 15, 381-398. 